\title{
Participation of Women Members in a Community - driven Development Project
}

\author{
S. Elakkiya ${ }^{1}$ and M. Asokhan ${ }^{2}$
}

\begin{abstract}
A community-driven development project named 'Pudu Vazhvu' was launched in Tamil Nadu in November 2005 with World Bank assistance. The goal of the project was to reduce poverty among the rural poor and other vulnerable groups and to promote their empowerment, through targeted assistance for productive livelihood activities, in a more enabling village environment, adopting Community Driven Development (CDD) approach. Under this project, rural women were grouped into Self Help groups to promote their livelihood status. Hence there is a need to study the CDD-SHGs effectiveness. The study was carried out in Namakkal district in Tamil Nadu as it is one of the districts in Tamil Nadu where Pudu Vazhvu project was implemented. A sample of 132 respondents was selected from two blocks (six villages) following Proportionate Random sampling technique. The present study was undertaken to find out the participation of women project members in various activities of CDD project. The study revealed that Pudu Vazhvu project SHG women members had participated in group meetings record and account maintenance, formulating the rules and regulations and in getting loans.
\end{abstract}

Keywords : Community driven development project; women members; Participation; Self Help Group; Pudhu vazhvu; Tamil Nadu

A Community - driven development project entitled, 'Pudu Vazhvu Project' was approved and launched in November 2005 and it was implemented over a six year period with World Bank assistance. The target population of this project was poor households, the most vulnerable section including the physically challenged and the marginalized communities. The project adopted community driven development approach involving village communities at every stage of project implementation. The target population was identified by Village communities using participatory methodologies. The project was implemented in 2,509 Village Panchayats in 70 Backward blocks spread over 15 districts. The goal of the project was reduction of poverty among the rural poor and other vulnerable groups and to promote their empowerment through targeted assistance for productive livelihood activities in a more enabling village environment adopting Community Driven Development (CDD) approach. The project was based on cardinal principles of equity, inclusion, facilitation, participation, transparency and accountability which are

1 PG scholar \& 2 Professor and Head (Agricultural Extension), Department of Agricultural Extension and Rural Sociology, TNAU, Coimbatore-641003

Received : 27-04-2018; Accepted : 08-05-2018 
adopted as key non-negotiable principles.

In participatory methodologies, social mapping and wealth ranking method is used to identify the target population i.e. below poverty line family members. The social mapping depicts the habitation pattern, nature of housing, social infrastructure: roads, drainage systems, schools, drinking water facilities, etc. It is made by people not by experts, not and drawn based on any scales. After social mapping, wealth ranking is conducted to select the Self Help Group members from Below Poverty Line families.

A Self-Help Group is a group of about 10 to 20 people, usually women from a similar class and region, who come together to form savings and credit organization. They use seed money and pool financial resources to make small interest bearing loans to their members to help pay for important needs (NABARD 2009).

This paper describes the participation of group members in project activities.

\section{METHODOLOGY}

The study was carried out in Namakkal district in Tamil Nadu as it is one of the districts in Tamil Nadu where Pudu Vazhvu CDD project was implemented. Erumapatti and Vennandur blocks were selected based on year of implementation of the project. Three villages from each block (Altogether six villages) were also selected based on the earliest year of implementation. Asample of 132 respondents was selected from six villages following Proportionate Random Sampling technique. Data were collected with the help of a well-structured and pre-tested interview schedule and analysed with suitable statistical techniques.

\section{FINDINGS AND DISCUSSION}

The extent of participation in this study was operationalized as the degree to which CDD project women members participate in various activities.. The findings on the level of participation are given under the following subheadings.

Participation in the CDD project SHG activities

The findings relevant to the participation in project SHG activities are given in Table 1.

Table 1.

Distribution of Respondents according to their Participation in the project Self Help Group activities

$(n=132)$

\begin{tabular}{|c|l|c|c|c|}
\hline SI. No. & \multicolumn{1}{|c|}{ Participation in Project SHG Activities } & $\begin{array}{c}\text { Total } \\
\text { score }\end{array}$ & $\begin{array}{c}\text { Mean } \\
\text { score }\end{array}$ & Rank \\
\hline 1. & In group meetings & 388 & 2.93 & I \\
\hline 2. & In electing the office bearers & 380 & 2.87 & IV \\
\hline 3. & In record and account maintenance & 383 & 2.90 & II \\
\hline 4. & In formulating the rules and regulations & 382 & 2.89 & III \\
\hline
\end{tabular}


Participation of Women Members in a Community - driven Development Project

\begin{tabular}{|c|l|c|c|c|}
\hline SI. No. & \multicolumn{1}{|c|}{ Participation in Project SHG Activities } & $\begin{array}{c}\text { Total } \\
\text { score }\end{array}$ & $\begin{array}{c}\text { Mean } \\
\text { score }\end{array}$ & Rank \\
\hline 5. & In running the SHG according to rules and regulations & 372 & 2.81 & $\mathrm{~V}$ \\
\hline 6. & $\begin{array}{l}\text { In formulating plans for the development of the } \\
\text { women members }\end{array}$ & 358 & 2.71 & VII \\
\hline 7. & In training the women members & 310 & 2.34 & $\mathrm{XII}$ \\
\hline 8. & In organizing trainings & 287 & 2.17 & $\mathrm{XV}$ \\
\hline 9. & In sharing the experiences of trainings undergone & 291 & 2.20 & $\mathrm{XIV}$ \\
\hline 10. & In giving technical advice to other members & 291 & 2.20 & $\mathrm{XIV}$ \\
\hline 11. & In imparting skills to other members & 291 & 2.20 & $\mathrm{XIV}$ \\
\hline 12. & In conducting exposure visits & 314 & 2.37 & $\mathrm{XI}$ \\
\hline 13. & In creating cohesiveness among the group members & 315 & 2.38 & $\mathrm{X}$ \\
\hline 14. & In reviewing the progress made & 316 & 2.39 & $\mathrm{IX}$ \\
\hline 15. & In conflict resolution & 313 & 2.37 & $\mathrm{XI}$ \\
\hline 16. & In getting loans & 364 & 2.75 & $\mathrm{VI}$ \\
\hline 17. & In meeting government officials & 303 & 2.29 & $\mathrm{XIII}$ \\
\hline 18. & In taking group decisions & & 2.40 & $\mathrm{VIII}$ \\
\hline
\end{tabular}

\section{Overall mean score $=\mathbf{2 . 5 1}$}

Based on the total and mean scores, ranks had been allotted to each activity, in group meetings (2.93), record and account maintenance (2.87), formulating the rules and regulations (2.89), electing the office bearers (2.87), running the SHG according to rules and regulations (2.81), getting loans (2.75) , formulating plans for development of the women members (2.71) were the activities with more mean scores than the overall mean score (2.51) and have been observed in the order of participation.

The activities such as taking group decision (2.40), reviewing progress made (2.39), creating cohesiveness among the group members (2.38), conflict resolution (2.37), exposure visit (2.37), training the women members (2.34), meeting government officials
(2.29), sharing the experiences of trainings undergone (2.20), giving technical advice to other members (2.20), imparting skills to other members (2.20), organizing trainings (2.17) were the activities with less mean scores than the overall mean score (2.51).

Most of the respondents in the study area were found to be in middle to young age categories and had middle level education. This might be the reason for majority of the respondents to participate regularly in group meetings, record and account maintenance, formulating the rules and regulations, electing the office bearers, running the SHG according to rules and regulations, getting loans, formulating plans for development of the women members. Whereas the involvement in other activities is less because SHG representative and the women members who 
availed loans occasionally played a major role.

Group leaders regularly motivate the members to actively participate in the project SHG activities. Hence more participation was observed among the respondents in project SHG activities. Thus, the activities which were simple and regularly carried out during the meetings of the SHG had more mean scores.

The possible reason might be that the women members who received loans and attended trainings regularly had showed regular participation in Project activities.

This finding is in conformity with findings of Sujeetha (2012).

\section{Participation in Economic Developmental} activities

The findings related to the participation in economic developmental activities are given in Table 2.

Table 2.

Distribution of Respondents according to their Participation in economic developmental activities

$(n=132)$

\begin{tabular}{|c|l|c|c|c|}
\hline SI. No & \multicolumn{1}{|c|}{$\begin{array}{c}\text { Participation in Economic Developmental } \\
\text { activities }\end{array}$} & Total score & $\begin{array}{c}\text { Mean } \\
\text { score }\end{array}$ & Rank \\
\hline 1. & In deciding about loan lending to members & 350 & 2.65 & I \\
\hline 2. & In fixing interest rate for purpose oriented loans & 349 & 2.64 & II \\
\hline 3. & In running the commercial venture & 287 & 2.17 & III \\
\hline 4. & $\begin{array}{l}\text { Arranging to get resources from supporting } \\
\text { Institutions }\end{array}$ & 249 & 1.88 & V \\
\hline 5. & $\begin{array}{l}\text { Purchasing raw materials for their commercial } \\
\text { venture / entrepreneurial activity }\end{array}$ & 252 & 1.90 & IV \\
\hline 6. & In marketing their produce & 248 & 1.87 & VI \\
\hline 7. & $\begin{array}{l}\text { Participation in the product exhibitions conducted } \\
\text { by Government and other agencies. }\end{array}$ & 200 & 1.51 & VII \\
\hline
\end{tabular}

Over all mean score $=2.09$

Data furnished is Table 2 reveal that deciding about loan lending to members (2.65), fixing interest rate for purpose oriented loans (2.64), running the commercial venture (2.17) were the economic activities that got higher mean scores than overall mean score (2.09).
Purchasing raw materials for their commercial venture / entrepreneurial activity (1.90), arranging to get resources from supporting Institution (1.88), in marketing their produce (1.87), participation in the product exhibitions conducted by Government and other agencies were the economic activities 
Participation of Women Members in a Community - driven Development Project

that got low mean scores than the overall mean score (2.09).

In the study area, credit institutions and the banks were helpful to SHG members in sanctioning loan for starting entrepreneurial ventures and also the interest changed was very low compared to other financial institutions. This might be the reason for majority of the respondents to participate regularly in deciding about loan lending to members, fixing interest rate for purpose oriented loans and running commercial ventures. To enable project SHG members to sell their products,

exhibitions were organized under the scheme Mahalirthittam in Namakkal district. Thus the respondents had regular participation in marketing their produce which was one of the economic activity.

The above finding is in agreement with the findings of Mary (2012).

\section{Participation in Social Developmental activities}

The responses regarding participation pattern project SHG members in social developmental activities were collected and are given in Table 3.

Table 3.

Distribution of Respondents according to their Participation in Social Developmental Activities

\begin{tabular}{|c|l|c|c|c|}
\hline SI.No & \multicolumn{1}{|c|}{$\begin{array}{c}\text { Participation in Social Developmental } \\
\text { activities }\end{array}$} & $\begin{array}{c}\text { Total } \\
\text { score }\end{array}$ & Mean score & Rank \\
\hline 1. & $\begin{array}{l}\text { Participation in village developmental } \\
\text { works }\end{array}$ & 285 & 2.15 & VI \\
\hline 2. & Participation in social action programmes & 288 & 2.18 & V \\
\hline 3. & Participation in gram sabha meeting & 326 & 2.46 & IV \\
\hline 4. & $\begin{array}{l}\text { Participation in VPRC (Village Poverty } \\
\text { Reduction Committee) }\end{array}$ & 368 & 2.78 & I \\
\hline 5. & $\begin{array}{l}\text { Participation in SAC (Social Audit } \\
\text { Committee) }\end{array}$ & 353 & 2.67 & III \\
\hline 6. & $\begin{array}{l}\text { Participation in PLF (Panjayat Level } \\
\text { Federation) }\end{array}$ & 366 & 2.77 & II \\
\hline
\end{tabular}

Overall mean score $=2.50$

Table 3 indicates that more participation was observed with participation in Village Poverty Reduction Committee (2.78) followed by participation in Panchayat Level Federation (2.77), participation in Social Audit committee (2.67). Participation in Gram Sabha meeting (2.46), Participation in social action programmes (2.18) and Participation in village developmental works (2.15) respectively.

The possible reason might be that the CDD project SHGs had better linkage with local Institutions and they are actively involved in addressing social issues viz., creating awareness on school drop out 
children, dengue awareness campaign and women rights campaign this project, VPRC and PLF were giving the loan amount to CDD project SHG members. This might be the reason for more participation in Village Poverty Reduction Committee, Panchayat Level Federation and Social Audit Committees.

After joining the Pudu Vazhvu (CDD) project, the rural women members were able to participate in SHG'social and economic activities. Due to these activities, the women project members were able to avail loan and run commercial ventures. Important activities like cohesiveness among the group members, marketing their produce are not known to the project women members. Thus, adequate training, meeting and exposure visits can be organized to train the project women members in these areas.

\section{REFERENCES}

Mary, K.J, (2012). Impact of Dynamics of Self Help Group on Rural Women EmpowermentA Critical Analysis. Unpublished Ph.D Thesis, $A C \&$ RI, TNAU, Coimbatore.

NABARD, (2009). Banking with the poor: SHGBank-linkage programme in Andhra Pradesh. Department of Rural Development, Government of Andhra Pradesh, Hyderabad, India.

Sujeetha, T.N. (2012). Empowerment of tribal women through SHGs- an analysis. Unpublished M.Sc. (Ag.) Thesis, AC \& RI, TNAU, Coimbatore.

http://www.coimbatore.nic.in/drda/ Pudhuvaazhvu.pdf

http://pubdocs.worldbank.org / en/623561459872407029/ARetrospective-Impact-Evaluation-of-theTamil-Nadu-Empowerment-and-PovertyAlleviation-Pudhu-Vaazhvu-Project.pdf 